\title{
Abstention Doctrine Today
}

\section{Citation}

Martha A. Field, Abstention Doctrine Today, 125 U. Pa. L. Rev. 590 (1977).

\section{Published Version}

http://scholarship.law.upenn.edu/penn_law_review/vol125/iss3/3/

\section{Permanent link}

http://nrs.harvard.edu/urn-3:HUL.InstRepos:12991691

\section{Terms of Use}

This article was downloaded from Harvard University's DASH repository, and is made available under the terms and conditions applicable to Other Posted Material, as set forth at http:// nrs.harvard.edu/urn-3:HUL.InstRepos:dash.current.terms-of-use\#LAA

\section{Share Your Story}

The Harvard community has made this article openly available.

Please share how this access benefits you. Submit a story.

\section{Accessibility}




\title{
THE ABSTENTION DOGTRINE TODAY*
}

\author{
Martha A. Field $\dagger$
}

Since 1941, when the Supreme Court decided Railroad Commission v. Pullman Co., ${ }^{1}$ abstention has become an accepted procedure in the federal courts. By abstention I refer to "Pullman abstention," which comes into play when a federal court is faced with an unclear issue of state law whose resolution might avoid or modify a federal constitutional question. I am not going to discuss the quite different doctrine, embodied in the Younger v. Harris decision, ${ }^{2}$ counseling against federal interference with state criminal proceedings, although that doctrine as well is sometimes termed "abstention."

Pullman abstention has as its purpose avoiding federal court error on state law questions that arise in federal constitutional cases and that are within the federal courts' pendent jurisdiction. Two risks are thought to result from a federal court ruling erroneously on such state issues: The court may needlessly have to reach a federal constitutional issue that a proper interpretation of state law does not in fact present; or the federal court may interfere with legitimate state policy by interpreting state legislation more narrowly than the state judiciary would interpret it. The mechanism for avoiding federal error in the interpretation of state law is to remit the parties to the state courts for decision of the unclear state law question. The parties retain the right to return to the federal forum for decision of the federal issues in the case, ${ }^{3}$ unless the state question proves dispositive of the controversy. Indeed, the federal court usually retains jurisdiction of the lawsuit while the parties pursue their state law remedies. ${ }^{4}$

* This Article was developed from a speech delivered at the 46 th Annual Judicial Conference of the Fourth Circuit, held at White Sulphur Springs, West Virginia, in June 1976.

† Associate Professor of Law, University of Pennsylvania. A.B. 1965, Radcliffe College; J.D. 1968, University of Chicago Law School. Member, District of Columbia Bar.

1312 U.S. 496 (1941).

2401 U.S. 37 (1971).

${ }^{3}$ See England v. Louisiana State Bd. of Medical Examiners, 375 U.S. 411 (1964).

${ }^{4}$ For a more thorough exposition of the basics of the Pullman abstention doctrine and the author's views concerning it, see Field, Abstention in Constitutional Cases: The Scope of the Pullman Abstention Doctrine, 122 U. PA. L. Rev. 1071 (1974). 
The basic theory behind Pullman abstention may seem attractive, in that erroneous decisions are minimized by splitting the lawsuit and allowing each jurisdiction, state and federal, to make an authoritative pronouncement on its own law. From the outset, however, Pullman abstention has proved far from ideal in practice. The extreme delays inherent in the abstention procedure, and the attendant expense, have been chronicled many times. Essentially, the parties to a case in which abstention is ordered must undergo two lawsuits instead of one, because their cause is bifurcated between state and federal courts. When a federal court abstains in an action before it, the plaintiffs must commence a new lawsuit in state trial court, usually a declaratory judgment action, to have the unclear issue of state law resolved. They must work their way up through the state appellate system, usually without getting any priority on crowded state dockets, before the state issue is settled, so that they can return to the federal system for resolution of federal issues, with the attendant appeals. ${ }^{5}$ The prospect is hardly a happy one for litigants. It may deter them from seeking a federal forum in the first instance, or it may, once abstention is ordered, induce them to cut their costs by presenting all issues to the state court for decision and waiving their right to return to federal court on the federal issues. ${ }^{6}$ Plaintiffs in federal constitutional cases seem a singularly inappropriate group thus to discourage from access to the federal courts.

The delay and expense inherent in the abstention procedure are legendary, and have caused some judges and commentators to bemoan the doctrine from the outset. ${ }^{7}$ Those qualities are exacerbated, however, by three less often noted problems with Pullman abstention, which I wish to point out here. The first relates to the reviewability of abstention decisions; the second involves misuse of the abstention procedure to accomplish pur-

${ }^{3}$ The right to factfinding by a federal tribunal, see England v. Louisiana State Bd. of Medical Examiners, 375 U.S. 411, 416-17 (1964), may cause a federal court at this stage to make new factual findings, even concerning issues that the state court has already determined. If it should reach conclusions differing from those of the state judicial system, the state and federal facets of the lawsuit would presumably be decided according to conflicting factual theories.

${ }^{6}$ Voluntary presentation of all issues to the state court constitutes a waiver of the right to return to the federal forum for adjudication of the federal issues. England $v$. Louisiana State Bd. of Medical Examiners, 375 U.S. 411 (1964).

${ }^{7}$ E.g., Harrison v. NAACP, 360 U.S. 167, 180 (1959) (Douglas, J., dissenting). Kurland, Toward a Co-operatize Judicial Federalism: The Federal Court Abstention Doctrine, 24 F.R.D. 481 (1959); Wright, The Abstention Doctrine Reconsidered, 37 TEx. L. Rev. 815 (I959). 
poses other than clarification of state law; the third concerns the possibility that abstention in a particular case will not result in any state supreme court pronouncement on the controverted state law question. I conclude that the abstention procedure is not worth its costs; if state court clarification of state issues is deemed necessary, certification of the issues directly to the state supreme court is a preferable device.

\section{Issues Concerning Pullman Abstention}

\section{A. Reviewability of Abstention Decisions}

The law is unsettled concerning whether or not abstention orders are appealable. ${ }^{8}$ The Supreme Court has reviewed several decisions to abstain ${ }^{9}$ without clearly resolving the issue of appealability. Indeed, in one case the Court reviewed the abstention order while limiting its grant of certiorari to exclude the issue of the order's appealability! ${ }^{10}$

There are three possible avenues to appellate review of abstention orders. The first would characterize the orders as "final decisions" appealable under section 1291 of the Judicial Code. ${ }^{11}$ This approach has Supreme Court support, ${ }^{12}$ but several abstention orders that the Supreme Court has reviewed have arguably been final decisions only because the abstaining court had referred all the issues in the case-federal as well as state-to the state judiciary. ${ }^{13}$ The appellant was thus "effectively out of

${ }^{8}$ Compare 9 Moore's Federal Practice $\uparrow 110.20$ [4.-2], at 251 (2d ed. 1975) (taking the position that abstention orders are appealable as long as no action is pending in the state courts when abstention is ordered), with American Law Institute, Study of THE Division of Jurisdiction Between STAte and Federal Courts 291 -92 (1969) (discussed in note 37 infra) (taking the position that abstention orders are not appealable).

${ }^{9}$ See, e.g., Lake Carriers' Ass'n v. MacMullan, 406 U.S. 498 (1972); NAACP v. Bennett, 360 U.S. 471 (1959); County of Allegheny v. Frank Mashuda Co., 360 U.S. 185 (1959); Louisiana Power \& Light Co. v. City of Thibodaux, 360 U.S. 25 (1959).

${ }^{10}$ Louisiana Power \& Light Co. v. City of Thibodaux, 360 U.S. 25, 26 n.1 (1959). There may be a reason peculiar to that case rendering the order appealable: The case was an eminent domain proceeding, which is an action at law, unlike the usual Pullman abstention proceeding, which is an action in equity. See notes 21-30 infra \& accompanying text. The Fifth Circuit had relied on this fact in holding the order appealable. City of Thibodaux v. Louisiana Power \& Light Co., 255 F.2d 774, 777-78 (5th Cir. 1958), rev'd on other grounds, 360 U.S. 25 (1959).

1128 U.S.C. $\S 1291$ (1970). This section gives the courts of appeals jurisdiction to review; the Supreme Court could then review their decisions under 28 U.S.C. $\$ 1254$ (1970).

${ }_{12}$ Idlewild Bon Voyage Liquor Corp. v. Epstein, 370 U.S. 713, 715 n.2 (1962).

${ }^{13}$ Lake Carriers' Ass'n v. MacMullan, 406 U.S. 498 (1972); Idlewild Bon Voyage Liquor Corp. v. Epstein, 370 U.S. 713, 715 n.2 (1962); County of Allegheny v. Frank Mashuda Co., 360 U.S. 185 (1959); $c f$. Turner v. City of Memphis, 369 U.S. 350 (1962); 
court"14 in those cases to a greater degree than he would be in the usual abstention situation, in which the federal district court retains jurisdiction of the cause and affords the parties a right to return to federal court for initial determination of the federal issues. Because the latter procedure clearly is required today, ${ }^{15}$ Pullman abstention decisions deviating from it should be reviewable in any event under the All Writs Act $^{16}$ as abuses of discretion. ${ }^{17}$ Decisions that do follow the proper procedure, on the other hand, could not as readily be characterized as final under the effectively-out-of-court rationale. One might argue that they also are final because the long road that litigants must travel in order to return to federal court may well discourage their return. Or one might stress the importance to the litigants of the abstention decision and the unremediable hardship imposed by a wrongful order that is not immediately reviewed. ${ }^{18}$ These rationales for finality, however, are uncertain of success. ${ }^{19} \mathrm{Un}$ -

NAACP v. Bennett, 360 U.S. 471 (1959) (in both Turner and Bennett, the district court had purported to refer only state issues to the state court, but at a time when it was not yet established that there is a right after abstention to return to federal court). Idlewild is the only one of the above cases in which the Court made reference to the issue of reviewability.

14 Idlewild Bon Voyage Liquor Corp. v. Epstein, 370 U.S. 713, 715 n.2 (1962) (quoting the court of appeals' opinion, Idlewild Bon Voyage Liquor Corp. v. Rohan, 289 F.2d 426, 428 (2d Cir. 1961)).

${ }^{15}$ England v. Louisiana State Bd. of Medical Examiners, 375 U.S. 411 (1964).

${ }^{16} 28$ U.S.C. $\$ 1651$ (1970).

${ }^{17}$ See text accompanying notes $38-40$ infra.

${ }^{18}$ Cases that might provide a basis for this finality argument include: Cox Broadcasting Corp. v. Cohn, 420 U.S. 469, 478 (1975); Gillespie v. United States Steel Corp., 379 U.S. 148, 152-54 (1964); Mercantile Nat'l Bank v. Langdeau, 371 U.S. 555, 557-58 (1963); Construction Laborers v. Curry, 371 U.S. 542, 548-50 (1963); Cohen v. Beneficial Indus. Loan Corp., 337 U.S. 541, 545-47 (1949).

In Cox Broadcasting Corp., Mr. Justice Rehnquist, dissenting from the Court's conclusion of finality in that case, gave an explanation of the Court's holdings of finality in Curn and Langdeau, cases involving review of state court decisions, that would be helpful in an argument that orders of abstention are final. He said that Cumy and Langdeau "are based on the understandable principle that where the proper forum for trying the issue joined in the state courts depends upon the resolution of the federal question raised on appeal, sound judicial administration requires that such a question be decided by this Court, if it is to be decided at all, sooner rather than later in the course of the litigation." 420 U.S. at 506. Orders of abstention similarly might be considered final because of the importance of determining the proper forum at the outset, though clearly no review at all will be had of abstention orders unless it is had immediately.

${ }^{19}$ In Catlin v. United States, 324 U.S. 229 (1945), the Court defined a final judgment as one that "ends the litigation on the merits and leaves nothing for the court to do but execute the judgment." Id. at 233. See also Southern Pac. Co. v. Gileo, 351 U.S. 493, 495-96 (1956); Clark v. Williard, 292 U.S. 112,118 (1934). In Schoenamsgruber v. Hamburg Am. Line, 294 U.S. 454, 456 (1935), the Court held that an order staying proceedings pending arbitration was not final. 
less one of them is adopted, section 1291 is a very limited means for review of abstention orders. ${ }^{20}$

A second possible avenue of review is section 1292(a) of the Judicial Code, giving courts of appeals "jurisdiction of appeals from: (1) Interlocutory orders of the district courts . . granting, continuing, modifying, refusing, or dissolving injunctions. .

"21 The Supreme Court could then review the decisions under section 1254 of the Judicial Code. ${ }^{22}$ Stays issued in federal proceedings so that the parties will repair to state court could be reviewable under this provision if they were considered injunctions against the federal proceedings. ${ }^{23}$ They have traditionally been so regarded only in legal proceedings and not in equitable ones. Through a series of Supreme Court decisions, ${ }^{24}$ the rule has evolved that

[a]n order staying or refusing to stay proceedings in the District Court is appealable under $\S 1292(a)(1)$ only if (A) the action in which the order was made is an action which, before the fusion of law and equity, was by its nature an action at law; and (B) the stay was sought to permit the prior determination of some equitable defense or counterclaim. ${ }^{25}$

Although little in the way of reasoning supports this rule, ${ }^{26}$

${ }^{20}$ Some court of appeals cases hold abstention orders final although the abstaining court retained jurisdiction. Druker v. Sullivan, 458 F.2d 1272 (Ist Cir. 1972) (seemingly deeming all abstention orders "clearly appealable," id. at 1274 n.3); Amdur v. Lizars, 372 F.2d 103 (4th Cir. 1967) (saying such stays are usually not appealable but that the one in question was because it amounted to a dismissal); $c f$. Kelley v. Metropolitan County Bd. of Educ., 436 F.2d 856 (6th Cir. 1970), cert. denied, 409 U.S. 1001 (1972) (reviewing as final a stay to await Supreme Court decisions because the rights of the parties required immediate adjudication); McSurely v. McClellan, 426 F.2d 664 (D.C. Cir. 1970) (holding final a stay of federal civil proceedings pending federal criminal proceedings against the defendants because of the indefiniteness of the stay and because the defendants' rights would be irretrievably lost unless adjudicated immediately). 9 Moore's Federal Practice 1110.20 [4.-2], at 251 (2d ed. 1975), takes the position that an abstention order is final, so long as the state law action deferred to has not commenced at the time abstention is ordered.

2128 U.S.C. \& 1292(a)(1) (1970).

${ }^{22}$ Id. \& 1254 . Under the same reasoning, the Supreme Court could review abstention orders of three-judge courts. See id. § 1253 (1970).

${ }^{23}$ Alternatively, they would be characterized simply as rulings regarding the manner in which the proceedings would be tried and would not be appealable. See City of Morgantown v. Royal Ins. Co., 337 U.S. 254, 257 (1949).

24 Baltimore Contractors, Inc. v. Bodinger, 348 U.S. 176 (1955); City of Morgantown v. Royal Ins. Co., 337 U.S. 254 (1949); Ettelson v. Metropolitan Life Ins. Co., 317 U.S. 188 (1942).; Enelow v. New York Life Ins. Co., 293 U.S. 379 (1935).

${ }^{25}$ Jackson Brewing Co. v. Clarke, 303 F.2d 844, 845 (5th Cir.) (footnote omitted) (emphasis in original), cert. denied, 371 U.S. 891 (1962).

${ }^{26}$ What reasoning exists is too esoteric to reproduce in any detail. The basic theory 
and although it is widely criticized, ${ }^{27}$ most courts still follow it today. If it is adhered to, the utility of section 1292(a)(1) in Pullman abstention cases is severely limited. ${ }^{28}$ The second part of the rule, requiring that the purpose of the stay be to allow prior determination of an equitable defense, could be satisfied if a court were willing to regard as equitable a declaratory judgment action; it is such an action that usually will be commenced in state court after an abstention order. ${ }^{29}$ The first part

builds on the fact that prior to 1915 a defendant could present an equitable defense to a legal action only by bringing an independent suit in equity to enjoin the action at law. Therefore, when an equitable defense to an action at law is interposed today, the theory is that the defendant is really seeking the aid of equity to enjoin the action, and an order staying or refusing to stay is one granting or refusing an injunction. This despite the merger of law and equity in 1938.

The rationale, by its terms, is not available when the defense is not equitable or when the original action is not at law.

The most coherent summary of the cases and explanation of how the theory evolved can be found in C. Wright, Federal Courts 460-61 (2d ed. 1970).

${ }^{27}$ Id.; 9 Moore's Federal. Practice I 110.20[3], at 245-46 (2d ed. 1975). Many courts, including the Supreme Court, have criticized the rule though they have felt obliged to follow it. See, e.g., Chapman v. Int'l Ladies Garment Workers' Union, 401 F.2d 626, 628 (4th Cir. 1968); Travel Consultants, Inc. v. Travel Management Corp., 367 F.2d 334 (D.C. Cir. 1966); Glen Oaks Utils., Inc. v. City of Houston, 280 F.2d 330, 333, 337 (5th Cir. 1960). The Supreme Court in Baltimore Contractors, Inc. v. Bodinger, 348 U.S. 176,185 (1955), felt that relief from the rule must come from Congress, not the Court.

${ }_{28}$ Note, however, that one commentator believes that the rule does not properly apply to Pullman abstention cases and that 28 U.S.C. $\$ 1292(a)(1)(1970)$ allows appeal in those cases as long as injunctive relief is sought. 9 Moore's Federal Practice If 110.20[4.-2], at 25 I (2d ed. 1975). The courts have not agreed, however, see Mercury Motor Express, Inc. v. Brinke, 475 F.2d 1086 (5th Cir. 1973); Louisiana Power \& Light Co. v. City of Thibodaux, 255 F.2d 774, 777 (5th Cir. 1958), ret'd on other grounds, 360 U.S. 25 (1959), discussed in note 10 supra and in Jackson Brewing Co. v. Clarke, 303 F.2d 844, 846 (5th Cir.), cert. denied, 371 U.S. 891 (1962); Jewell v. Davies, 192 F.2d 670 (6th Cir. 1951), cert. denied, 343 U.S. 904 (1952); nor has the American Law Institute, see note 37 infra \& accompanying text.

${ }^{29}$ In Jackson Brewing Co. v. Clarke, 303 F.2d 844, 846 (5th Cir.), cert. denied, 371 U.S. 891 (1962), the court regarded a declaratory judgment action as analogous, for these purposes, to the old bill in equity, quia timet. It is not at all clear, however, that declaratory relief would be generally so regarded. See, e.g., Simler v. Connor, 372 U.S. 221, 223 (1963).

It might appear advantageous to one seeking to appeal an abstention order to characterize declaratory relief as legal rather than equitable with regard to the first part of the rule-requiring that the cause in which the order was made be at law. In American Safety Equip. Corp. v. J.P. Maguire \& Co., 391 F.2d 821, 824-25 (2d Cir. 1968), the court held that the declaratory judgment action brought before it should be considered legal (because absent the availability of that relief a legal action would have been brought) and that the stay pending arbitration was therefore appealable.

If declaratory judgments were considered legal, then Pullman abstention cases often would involve both equitable and legal relief because requests for declaratory relief often are joined to requests for an injunction. It is not clear how the law/equity distinction for appeals should apply in a situation in which both legal and equitable relief is sought, though a dominant-purpose test or an essential-nature-of-the-action test seems the prevalent solution. See, e.g., Western Geophysical Co. of Am., Inc. v. Bolt Assocs., Inc., 440 F.2d 765, 771 (2d Cir. 1971); Schine v. Schine, 367 F.2d 685, 688 (2d Cir. 
would be impossible to satisfy in most Pullman contexts, however, because Pullman abstention cases ordinarily will be in equity. ${ }^{30}$

In Glen Oaks Utilities, Inc. v. City of Houston, ${ }^{31}$ the United States Court of Appeals for the Fifth Circuit, believing that a prior Fifth Circuit decision adhering to the prevailing law/equity distinction "precluded [it] from saying that stay orders, in all cases where the decision of another court is awaited, are injunctive in nature and appealable," 32 found another way to review stay orders under section 1292(a)(1): The court held that the stay order in question "was for all practical purposes, a denial of the temporary injunction which was sought."33 Section 1292(a)(1)

1966) (Friendly, J., concurring); Alexander v. Pacific Maritime Ass'n, 332 F.2d 266, 268 (9th Cir. 1964); cf. Standard Chlorine of Del., Inc. v. Leonard, 384 F.2d 304 (2d Cir. 1967) (holding that an action should be considered equitable when both legal and equitable relief is sought unless the equitable relief can be characterized as "merely incidental," $i d$. at 309). Under these tests, the action would doubtless usually be considered equitable. See note 30 infra. And even if the plaintiff in a Pullman abstention case had the foresight to allege only declaratory relief, the action might well be considered equitable rather than legal, under the reasoning of American Safety Equipment, because absent the availability of declaratory relief an injunction probably would have been sought. Cf. Skelly Oil Co. v. Phillips Petroleum Co., 339 U.S. 667, 672-74 (1950) (existence of federal question jurisdiction in declaratory judgment proceeding depends on whether the action that would have been brought, absent the declaratory procedure, would have qualified for federal question jurisdiction).

${ }^{30}$ To some, it is the equitable discretion of the federal judge as chancellor that justifies the abstention procedure at all, see Railroad Comm'n v. Pullman Co., 312 U.S. 496, 500 (1941); $f f$. Louisiana Power \& Light Co. v. City of Thibodaux, 360 U.S. 25, 28 (1959) (the Court ordered abstention in an eminent domain action but analogized that type of proceeding to an equitable action); Burford v. Sun Oil Co., 319 U.S. 315, 317-18 (1943) (a federal court having jurisdiction of a suit to enjoin enforcement of a state commission's order may, in its sound equitable discretion, refuse to exercise its jurisdiction if granting relief would be prejudicial to the public interest); Harlow $v$. Ryland, 172 F.2d 784, 786 (8th Cir. 1949) (federal court, as court of law, must exercise jurisdiction to decide state law questions, unlike other cases in which federal court, as court of equity, may in exceptional circumstances decline to decide doubtful questions of state law), and the usual Pullman abstention case involves an attempt to enjoin state action as unconstitutional. On occasion, however, the Court has abstained in simple damage actions without mentioning the issue. Fornaris v. Ridge Tool Co., 400 U.S. 41 (1970) (per curiam); United Gas Pipe Line Co. v. Ideal Cement Co., 369 U.S. 134 (1962) (per curiam).

31280 F.2d 330 (5th Cir. 1960).

${ }^{32} I d$. at 333.

${ }^{33}$ Id. (emphasis added); see Clean Air Coordinating Comm. v. Roth-Adam Fuel Co., 465 F.2d 323 (7th Cir. 1972), cert. denied, 409 U.S. 1117 (1973); United States v. Lynd, 301 F.2d 818 (5th Cir.), cert. denied, 371 U.S. 893 (1962); Jewell v. Davies, 192 F.2d 670, 673 (6th Cir. 1951), cert. denied, 343 U.S. 904 (1952); $c f$. Mercury Motor Express, Inc. v. Brinke, 475 F.2d 1086 (5th Cir. 1973) (holding a stay order reviewable because it was accompanied by a denial of a preliminary injunction); Weiss v. Duberstein, 445 F.2d 1297 (2d Cir. 197i) (holding an order of abstention appealable under 28 U.S.C. § 1292(a)(1) (1970) because it was coupled with a denial of a motion for summary judgment that had the effect of a denial of a temporary injunction that the plaintiffs had sought). 
can thus allow appeal of some stay orders, even in equitable actions; it may, however, be of limited utility. Under that rationale, appeal is available, obviously, only when a temporary injunction is sought. ${ }^{34}$ In Glen Oaks, the court also emphasized that no relief was sought except for temporary and final injunctions; this could prove to limit the rule further. More basically, characterizing a district court's action as a refusal of a temporary injunction may not be possible when "a practical assessment of the case" shows "that the court's action did not even imply a preliminary assessment of the merits of the claim for injunctive relief, including the claim of irreparable injury." 35 The factors going into an abstention decision can easily be sufficiently independent of the merits of the cause that appeal will not lie under the Glen Oaks rationale.

Apparently on the theory that no appeals were available from stays issued in equitable proceedings, ${ }^{36}$ the reporters of the American Law Institute, writing in 1969 , believed that the law did not allow for appeal of abstention orders. ${ }^{37}$ They recommended retaining the ban on appeals and allowing review only under a third possible avenue of review: the All Writs Act. ${ }^{38}$ The All Writs Act would permit review by mandamus when the appellate court determines that the trial court has abused its discretion in staying an action. ${ }^{39}$ If this were the exclusive route

${ }^{34} \mathrm{Cf}$. Ferrara v. Louisiana, 443 F.2d 344 (5th Cir. 1971) (appeal dismissed because no injunction was sought and because the stay order issued by the district court was not equivalent to an injunction); Goldstein v. Cox, 396 U.S. 471 (1970) (construction of an analogous statute, 28 U.S.C. $\& 1253$ (1970), governing interlocutory appeals from three-judge courts to United States Supreme Court). For these purposes, preliminary or temporary injunctions are distinguished from temporary restraining orders. See, e.g., Grant v. United States, 282 F.2d 165 (2d Cir. 1960); Pennsylvania Motor Truck Ass'n v. Port of Philadelphia Marine Terminal Ass'n, 276 F.2d 931 (3d Cir. 1960); Connell v. Dulien Steel Prods., Inc., 240 F.2d 414 (5th Cir. 1957).

${ }^{35}$ Dellinger v. Mitchell, 442 F.2d 782, 789 (D.C. Cir. 1971); see Switzerland Cheese Ass'n v. E. Horne's Mkt., Inc., 385 U.S. 23, 25 (1966).

${ }^{36}$ See 43 ALI Proceedings 365-66 (1966) (remarks of Judge Friendly and Professor Field).

${ }^{37}$ The reporters' draft made no express provision for review of abstention orders and their commentary indicated their belief that the absence of an express provision would preclude appellate review except under the All Writs Act, 28 U.S.C. $\$ 1651$ (1970). AMERICAN LAW INSTITUTE, supra note 8, at 291-92.

${ }^{38}$ AMERICAN LAW INSTITUTE, supra note 8, at 291-92. The All Writs Act is codified at 28 U.S.C. $\S 1651$ (1970).

${ }^{39}$ See Dellinger v. Mitchell, 442 F.2d 782 (D.C. Cir. 1971); ACF Indus., Inc. v. Guinn, 384 F.2d 15 (5th Cir. 1967), cert. denied, 390 U.S. 949 (1968); Leesona Corp. v. Cotwool Mfg. Corp., 308 F.2d 895 (4th Cir. 1962); Lyons v. Westinghouse Elec. Corp., 222 F.2d 184 (2d Cir. 1955); International Nickel Co. v. Martin J. Barry, Inc., 204 F.2d 583, 585 (4th Cir. 1953); Kerotest Mfg. Co. v. C-O Two Fire Equip. Co., 342 U.S. 180, 
to review, as the American Law Institute prefers, ${ }^{40}$ review would be limited to extraordinary cases.

Thus far, the discussion has concerned primarily review of lower court decisions to abstain. When a court refuses a request for abstention and instead proceeds with the cause, the ruling clearly is reviewable, but typically it is not reviewed immediately; ${ }^{41}$ it is reviewed only after the trial court has disposed of

185 (1952); AMERICAN LAW INSTITUTE, supra note 8, at 291-92.

Query whether abstention is appropriately deemed a discretionary doctrine, because federal appellate courts both reverse lower court orders of abstention, e.g., Griffin v. County School Bd., 377 U.S. 218 (1964); Turner v. City of Memphis, 369 U.S. 350 (1962), and order abstention themselves in the first instance, e.g., Harrison v. NAACP, 360 U.S. 167 (1959); Railroad Comm'n v. Pullman Co., 312 U.S. 496 (1941), and do not seem in any case to allow the district court's ruling to stand for the simple reason that the district court so ruled, see Clay v. Sun Ins. Office, 363 U.S. 207, 223 n.17 (1960) (Black, J., dissenting). But see, e.g., American Law Institute, supra note 8, at 29, quoted in note 30 supra; Harman v. Forssenius, 380 U.S. 528, 534, 537 (1965); Louisiana Power \& Light Co. v. City of Thibodaux, 360 U.S. 25, 27 n.2 (1959). Were mandamus the sole route to appellate review, however, as it sometimes is today, see Dellinger v. Mitchell, 442 F.2d 782 (D.C. Cir. 1971), only egregious error on the part of the trial court would be correctible and less evident error would be left undisturbed. In effect, therefore, trial courts would be accorded a measure of discretion.

40 AMERICAN LAw InstituTe, supra note 8, at 291-92.

${ }^{41}$ Of the three avenues of review discussed above, the All Writs Act, 28 U.S.C. $\S 1651$ (1970), could conceivably allow immediate review of refusals to abstain. The American Law Institute, endorsing the All Writs Act procedure, noted that mandamus would be available "[i]f the rare case should ever arise in which refusal to abstain was such an improvident exercise of discretion vested in the district court that appellate review was indicated. . . " AMERICAN LAW INSTITUTE, supra note 8, at 292.

The only other avenue to immediate review of refusals to abstain would involve characterizing a request for abstention as a request for an injunction against the federal proceeding. If that characterization were accepted across the board, then grants or refusals of the requested "injunctive" relief would be appealable under 28 U.S.C. $\S 1292(a)(1)(1970)$. As noted above, however, text accompanying notes 21-30 supra, the law/equity distinction prevents this avenue of review from having much significance in the Pullman abstention context. And advocates of abolition of the distinction would not increase instances of appealability; usually their position is that appeals should be allowed in none of these cases, not in all of them. See, e.g., C. WRIGHT, supra note 26, at 460-6I; 9 Moore's Federal Practice $\$ 110.20$ [3], at 245-46 (2d ed. 1975). But see Glen Oaks Utils., Inc. v. City of Houston, 280 F.2d 330, 333 (5th Cir. 1960).

The other rationale for appealability under $\$ 1292(a)(1)$ - the Glen Oaks, or denialof-temporary-injunction rationale-would be available only for grants of requests for abstention, not for refusals to abstain. Unlike a decision to abstain, which amounts to a decision not to grant the requested relief for the time being at least, a decision to proceed with the cause cannot be characterized as an interlocutory order "granting, continuing, modifying, refusing or dissolving injunctions, or refusing to dissolve or modify injunctions," 28 U.S.C. $\$ 1292(a)(1)$ (1970), because it says nothing bearing on the grant or refusal of the requested relief.

Moreover, a decision not to abstain has never been held final and hence appealable under 28 U.S.C. $\$ 1291$ (1970). (A finality argument would be difficult to make, because the court that decides not to abstain generally proceeds directly to determine the merits. Note, however, that Mr. Justice Rehnquist's point, quoted in note 18 supra, would support finality here.) 
the case on its merits. ${ }^{42}$ Problems concerning piecemeal review are not present, therefore, but the practice has problems of its own: It means that a party who has had his case decided on the merits in the federal district court and the court of appeals may face an abstention decision in the Supreme Court of the United States. ${ }^{43}$ Indeed, that Court may raise the abstention issue on its own motion, though no mention has been made of it earlier in the litigation. ${ }^{44}$ The parties are then remanded to state court to start the litigation anew on state issues, perhaps years after their lawsuit began, and the disposition of the federal issues that have already been fully adjudicated is set aside. ${ }^{45}$

The costs of such a system are obvious, and yet a solution to the problem is not. Although the current system is wasteful, an earlier review would interrupt and delay the lawsuit, often unnecessarily. The difficulty in reaching an acceptable solution is largely a function of the looseness of the standards for abstention. Ideally, the criteria for abstention should be sufficiently definite that they could be applied at the outset of the litigation

${ }^{42}$ This method of proceeding obviously is not available when the court's decision favors abstention; unless review is immediate, the decision is not reviewable at all.

${ }^{43}$ E.g., Harris County Comm'rs' Court v. Moore, 420 U.S. 77 (1975); Harrison v. NAACP, 360 U.S. 167 (1959); Railroad Comm'n v. Pullman Co., 312 U.S. 496 (1941); cf. Lehman Bros. v. Schein, 416 U.S. 386, 393 (1974) (Rehnquist, J., concurring) (complaining that "petitioners seek to upset the result of more than two years of trial and appellate litigation on the basis of a point which they first presented to the Court of Appeals upon petition for rehearing"); Hostetter v. Idlewild Bon Voyage Liquor Corp., 377 U.S. 324, 329 (1964) (refusing to hold under the circumstances that the district court should have abstained).

${ }^{44}$ Wisconsin v. Constantineau, 400 U.S. 433, 439, 443 (1971) (dissenting opinions of Burger, C.J. \& Black, J.); $c f$. England v. Louisiana State Bd. of Medical Examiners, 375 U.S. 411 (1964) (district court abstained sua sponte); Harris County Comm'rs' Court v. Moore, 420 U.S. 77, $81 \&$ n.3 (1975) (the parties had not raised the abstention issue with any clarity); Louisiana Power \& Light Co. v. City of Thibodaux, 360 U.S. 25 (1959) (district court abstained sua sponte).

${ }^{45}$ In Harris County Comm'rs' Court v. Moore, 420 U.S. 77 (1975), for example, the district court had enjoined a challenged redistricting plan on the ground that it violated the fourteenth amendment. The Supreme Court on review directed the district court to abstain on the state issue before reaching the federal constitutional one. The state issue, which the district court had not decided presumably because it was unclear that the plaintiffs had raised it, see id. at $81 \& \mathrm{n} .2$, was whether the redistricting plan violated the state constitution.

In Reetz, v. Bozanich, 397 U.S. 82 (1970), the district court had held that the challenged provisions violated both the Alaska Constitution and the Federal Constitution. The Supreme Court directed the state court to abstain on the state issue before reaching the federal one.

In both cases, decision of the state issues would not change the posture of the federal issue but might simply affect the necessity of reaching the federal issue. It seems unfortunate for a decision with this purpose to be rendered at such a late stage, after the federal issue, which undoubtedly is in the case, has been fully litigated by the parties and has been fully adjudicated by a three-judge district court. 
without substantial risk of error; the long process of litigating the question which is the proper tribunal in which to litigate could thereby be foregone. But because the availability of abstention depends primarily upon the degree of unclarity of state legal issues, and because some ambiguity can be detected in almost any legal rule, the instances in which abstention should be ordered do not lend themselves to any definite codification.

When the standards provide such little guidance, it is difficult to leave the subject to the unreviewable discretion of trial judges. It would be particularly troublesome to do that, in my view, in instances when abstention is ordered, for that decision can be enormously important to the litigant who has chosen the federal forum, and he has a statutory right to pursue his cause there. Even if the abstention doctrine legitimately modifies that right, at least the federal system should assure itself before allowing the litigant's ouster from federal court that his case falls within the scope of the abstention doctrine.

I would suggest, therefore, allowing review of decisions to abstain, as is the practice today, and clarifying the doctrinal basis for that review. (My own approach would be to deem abstention orders final decisions despite the retention of federal jurisdiction, because of the importance of the decision to the litigation and because it contemplates at least an extensive interruption in the exercise of federal jurisdiction. ${ }^{46}$ ) It seems to me less troublesome, however, for refusals of requests for abstention to be unreviewable. ${ }^{47}$ Support for the view that declining to abstain in a case appropriate for abstention is not nearly as serious as abstaining erroneously can be found in last Term's decision in Colorado River Water Conservation District $v$. United States. There the Court stressed that "[a]bstention from the exercise of federal jurisdiction is the exception, not the rule. 'The doctrine of abstention .... is an extraordinary and narrow exception to the duty of a District Court to adjudicate a controversy properly before it" "48 Declining to abstain is not as serious because federal

${ }^{46}$ See cases cited notes 18 \& 20 supra.

47 The possibility of immediate review under the All Writs Act for abuses of discretion could remain. I share the skepticism of the American Law Institute, however, that such a case will ever arise. See AMERICAN LAw INSTITUTE, supra note 8, at 292, quoted in note 41 supra.

${ }^{48}$ Colorado River Water Conserv. Dist. v. United States, 424 U.S. 800,813 (1976) (quoting County of Allegheny v. Frank Mashuda Co., 360 U.S. 185, 188-89 (1959)). Elsewhere in the Colorado Rizer case, Mr. Justice Brennan referred-citing England v. Louisiana State Bd. of Medical Examiners, 375 U.S. 411 , 415 (1964); McClellan v. Car- 
jurisdiction to decide the state issues does exist. Moreover, district judges' capability concerning state law decisionmaking should not be overlooked or minimized; they are generally familiar with the law of the state in which they sit. The strongest argument in favor of unreviewability of decisions not to abstain, however, is avoidance of the costs of the current system. Allowing a trial judge in his unreviewable discretion to proceed with the lawsuit, of which the federal court in any event does have jurisdiction, seems to me preferable to allowing referral to state courts after full adjudication of the controversy.

Not only should a district court's refusal to abstain be a final determination that the case will be adjudicated in the federal forum. Also, raising the abstention issue for the first time on appeal should not be permissible. Nor should appellate courts abstain on their own motion. Abstention would thus be waivable, as it is not today. ${ }^{49}$ Insofar as abstention exists to protect the interests of the parties (especially the interest of the state as a party), it seems sensible to rely on the parties raising the issue, and doing so at the district court level, and not unfair to preclude them if they do not raise the issue at that time. Insofar as the doctrine is designed to protect federal interests, the costs to the system of entertaining suggestions of abstention after full determination of the merits seem to me too great to justify that practice. ${ }^{50}$

In sum, I would allow federal courts to review lower court orders of abstention, as they now do, because the need for review is greatest in those cases. I would, however, take away federal appellate courts' power to order abstention in the first instance, because the costs of abstention are greatest when a case has already been decided on its merits. Such a rule would aid the reviewability problem, however, only by minimizing the importance of the abstention device. It is very far from the current practice of allowing abstention at either level of the federal appellate system, even on the court's own motion.

land, 217 U.S. 268, 281 (1910); and Cohens v. Virginia, 19 U.S. (6 Wheat.) 264, 404 (1821) (dictum)-to "the virtually unflagging obligation of the federal courts to exercise the jurisdiction given them." 424 U.S. at 817.

${ }^{49} \mathrm{See}$ cases cited notes 43-44 supra.

${ }^{50}$ The federal interest that abstention sometimes serves is the federal policy of avoiding federal constitutional decisionmaking. For an example, see note 68 infra. When abstention is considered after the trial court has disposed of the controversy, the federal constitutional questions have already been decided, at least at the trial court level, or else the state law has been interpreted in such a way as to avoid them. 


\section{B. Misuse of Abstention}

The second problem that I wish to mention concerning abstention is a tendency on the part of some federal courts to utilize the abstention procedure for purposes other than those for which it was designed. As stated earlier, the aim of abstention is to obtain the correct solution to a difficult and important question of state law, in order to facilitate the correct disposition of a federal lawsuit; delay is an unfortunate by-product of the procedure. A survey of abstention decisions, however, raises the question whether delay is not sometimes the aim of the abstention procedure, and the desirability of obtaining a clarifying state decision simply the excuse for the delay. When, for example, a lawsuit presents a federal constitutional attack on a state program that does not seem politic at the moment to resolve, abstention may appear a convenient device for removing the parties from federal court, for the time being at least. Even if they persist in demanding a federal forum to resolve their federal claims, abstention will put them off for a number of years.

The principal standard for abstention, which relates to unclarity in the state issue, is so much a question of degree and is so subjective that misuse of the abstention doctrine cannot be detected with any assurance and also cannot be controlled effectively. Yet, an examination of a series of abstention decisions does suggest that in situations in which the enunciated tests apply equally, abstention is sometimes ordered and is sometimes not, ${ }^{51}$ and that federal judicial views concerning the merits of the federal cause of action are often the impetus for an abstention ruling, quite apart from the need for clarification of state law. A Justice committed to environmental controls who generally opposes abstention, for example, may be the first to abstain in an environmental case in which the lower court ruling was unfavorable to the environmentalists. The lack of clarity in state law he detects to justify the abstention seems largely illusory. ${ }^{52}$ Absten-

${ }^{51}$ Compare Harman v. Forssenius, 380 U.S. 528 (1965) and Davis v. Mann, 377 U.S. 678 (1964) (in which the Court ruled against abstention because of the clarity of the state law issues), with Lake Carriers' Ass'n v. MacMullan, 406 U.S. 498 (1972), Fornaris v. Ridge Tool Co., 400 U.S. 41 (1970), Reetz v. Bozanich, 397 U.S. 82 (1970), and Harrison v. NAACP, 360 U.S. 167 (1959) (in which the Court deemed state law sufficiently ambiguous to require abstention).

${ }^{52}$ Most frequently, Pullman abstention cases involve individuals attacking state statutes as violations of their civil liberties. The plaintiffs' interests opposed to abstention are individual civil liberties interests; state interests favor it. See, e.g., Wisconsin v. Constantineau, 400 U.S. 433 (1971); Harman v. Forssenius, 380 U.S. 528 (1965); Harri- 
tion then becomes merely a device to set aside a lower court ruling thought undesirable for reasons having no relation to the abstention doctrine. ${ }^{53}$

If I am correct in detecting the existence of this practice, it is an unconscionable one. A wish to avoid or postpone decision of a particular constitutional issue should not occasion abstention when the federal tribunal has no real need for state advice concerning state law. Even if one accepts Professor Bickel's thesis that the federal courts (and particularly the Supreme Court) may properly invoke justiciability doctrines to avoid making decisions that seem impolitic, ${ }^{54}$ the abstention doctrine is not an appro-

son v. NAACP, 360 U.S. 167 (1959); Railroad Comm'n v. Pullman Co., 312 U.S. 496 (1941) (the most substantial attack on the challenged order was raised by intervenors, claiming unconstitutional racial discrimination). Lake Carriers' Ass'n v. MacMullan, 406 U.S. 498 (1972), however, involved private companies' attacks on a state statute protecting the environment. Business interests, then, instead of individual civil liberties interests, stood in the posture of opposing abstention, and a vote for abstention was a vote favoring environmental controls. Mr. Justice Brennan authored the opinion of the Court in Lake Carriers, an opinion that ordered abstention. Although Mir. Justice Brennan's statements concerning abstention in that opinion appear consistent with his remarks on abstention elsewhere, it is somewhat unusual to find him among the Justices considering state law "far from clear," 406 U.S. at 511 , for purposes of ordering abstention, when there is dissent on that issue. See, e.g., Harrison v. NAACP, 360 U.S. 167 (1959). The shift in Chief Justice Burger's position concerning abstention that the Lake Carriers situation brought about is a more noticeable one. Earlier the Chief Justice had taken the position that a state should have the first opportunity to pass upon a state statute without regard to whether it is ambiguous, and that plaintiffs' interests are adequately served by the availability of a state forum. Wisconsin v. Constantineau, 400 U.S. $433,440-43$ (1971). The Chief Justice also had previously been rather quick to find uncertainty in state law, and to order abstention on that basis. Id. at 440 n.l. In Lake Carriers, however, the Chief Justice joined an opinion dissenting from the order of abstention; taking the position that the challenged state law, though unconstrued, was not ambiguous; and emphasizing the plaintiffs' right to choose a federal forum to adjudicate their controversy.

Mr. Justice Douglas, ordinarily a vociferous opponent of abstention, see, e.g., Harris County Comm'rs' Court v. Moore, 420 U.S. 77, 89 (1975) (dissenting opinion); Manard v. Miller, 405 U.S. 982 (1972) (dissent from affirmance of order to abstain); England v. Louisiana State Bd. of Medical Examiners, 375 U.S. 411, 423 (1964) (separate opinion); Clay v. Sun Ins. Office, 363 U.S. 207, 227 (1960) (dissenting opinion); Harrison v. NAACP, 360 U.S. 167, 179 (1959) (dissenting opinion), has favored abstention in environmental cases. He joined the majority in the Lake Carriers case. He also wrote for the majority in Reetz v. Bozanich, 397 U.S. 82 (1970), in which the Supreme Court reversed a three-judge court decision holding unconstitutional, under state and federal law, an Alaska law limiting fishing rights on a grandfather-clause basis. The Court ordered abstention on the state constitutional issues.

${ }^{53}$ The crucial difference between this illegitimate use of abstention and the legitimate use of it to avoid unnecessary constitutional decisionmaking, described in note 68 infra, is that in the latter case the state issue is genuinely ambiguous and state law clarification is sought in good faith.

${ }^{54}$ A. Bickel, The Least Dangerous Branch $111-98$ (1962). But see Gunther, The Subtle Vices of the "Passive Virtues"-A Comment on Principle and Expediency in Judicial 
priate tool of avoidance. Its inappropriateness for this function is evident because it is not available in all constitutional cases but only in those that happen to contain state law issues. And unlike the justiciability doctrines, which bring the litigation to a close, abstention sends the litigants to state court with a promise of ultimate return to the federal court. Sending them on such a journey with an aim simply to postpone a federal decision disregards their legitimate interest in not incurring needless expense. It also adds unnecessarily to state court dockets, thereby ignoring and belittling state court needs to keep abreast of increasing caseloads. If delaying constitutional adjudication is ever a valid judicial objective, abstention, therefore, should not be its tool. Formulating a doctrine that focuses on the actual reasons for avoiding a decision, and that simply postpones or avoids the decision if that is the aim, would be far preferable to using abstention to force an essentially purposeless state court litigation.

\section{Absence of Input by the State Supreme Court}

A final point I wish to mention in connection with abstention is a very simple one, but it is the most fundamental objection of all: After the parties have undergone the lengthy process of litigating in lower state courts, an abstention may be rendered utterly purposeless in any given case by the state supreme court declining to review the lower court's ruling. A lower state court's guess as to how the state supreme court would decide the disputed state law issue may not be any more informed than the federal court's would be. And the whole purpose of abstention is to obtain the state supreme court's pronouncement. The United States Supreme Court has recognized this fact when it has abstained in situations in which lower state court opinions deciding the ambiguous issue were available but in which the state supreme court had not spoken. ${ }^{55}$ Yet the abstention procedure,

Review, 64 Colum. L. Rev. 1 (1964); Wechsler, Toward Neutral Principles of Constitutional Law, 73 Harv. L. Rev. 1, 7-8 (1959).

${ }^{55}$ Fornaris v. Ridge Tool Co., 400 U.S. 41 (1970). Fornaris involved construction of the Puerto Rican Dealers Contract Law, which provided that local dealers'. contracts with manufacturers were terminable by the manufacturers only when there was "just cause" to terminate. Fornaris sued in a Puerto Rican court for damages resulting from an allegedly unlawful termination, and defendant Ridge Tool Company removed to federal district court on diversity grounds. The district court denied the defendant's motion to dismiss on the ground of the alleged unconstitutionality of the Dealers Contract Law, whereupon an interlocutory appeal pursuant to 28 U.S.C. $\S 1292(b)$ (1970) was taken to the Court of Appeals for the First Circuit.

The First Circuit's opinion, 423 F.2d 563 (1970), notes that the Dealers Contract 
with all the costs it imposes, does not even necessarily lead to obtaining that state supreme court pronouncement which is the raison d'être for abstention!

\section{Should Pullman Abstention Be Abandoned in Favor of a Certification Procedure?}

The conclusion I would draw from all this is that Pullman abstention is not worth its costs. If some means of receiving state court input on unsettled issues of state law is deemed necessary, a certification procedure, under which a federal court that needs clarification of a state legal issue makes its inquiry directly to the supreme court of the state, seems vastly superior. Certification is currently available only in states that have chosen to authorize it. $^{56}$ The procedure is frequently criticized because of the delay

Law had been considered by the Superior Court of Puerto Rico in Construction Mach. \& Supplies Corp. v. Construction Mach. Co., Civ. No. 67-3349 (Super. Ct. of P.R., San Juan Section Dec. 23, 1968) and had been upheld in the face of a similar constitutional challenge. 423 F.2d at 564. Briefs submitted to the court of appeals cited the Construction Machine $E$ Supplies case and discussed the superior court's treatment of the "just cause" standard in the statute. Brief for Appellee at 35-36, 38, Fornaris v. Ridge Tool Co., 423 F.2d 563 (1st Cir. 1970) (quoting the superior court's discussion of "just cause"); Supplementary Brief for Intervenor at 4, Fornaris v. Ridge Tool Co., 423 F.2d 563 (1st Cir. 1970) (filed by the Commonwealth of Puerto Rico) (citing the Construction Machine $E$ Supplies opinion). Although noting in dicta that "[w]e do not agree with the position of the opponents of the act that the phrase 'just cause' is unconstitutionally vague and unspecific," $423 \mathrm{~F} .2 \mathrm{~d}$ at 568 , the court of appeals did hold the Dealers Contract Law unconstitutional because it retroactively altered contractual obligations in violation of due process. Id. at 567.

In its brief per curiam decision, the Supreme Court reversed and ordered abstention "until the Puerto Rican Supreme Court has authoritatively ruled on the local law question in light of the federal claims." 400 U.S. at 44 (footnote omitted). Beginning with the proposition that the Dealers Contract Law was "a rather vague Puerto Rican law that the Supreme Court of Puerto Rico has not authoritatively construed," id. at 43 (footnote omitted), the Court ignored the lower Puerto Rican courts' construction of "just cause" that had been presented to the court of appeals, preferring instead the authoritative construction of the term yet to be rendered by the supreme court of the Commonwealth.

${ }^{56}$ See, e.g., Colo. App. R. 21.1; Fla. Stat. \$ 25.031 (1946); Haw. Rev. Stat. $\S 602-36$ (1965); ME. R. Crv. P. 76 B; N.H. Rev. Stat. ANN. $\$ 490$ (1968) (APP. R. 21); WASH. REv. CODE $\$ 2.60$ (1965).

Congress could dispense with the need for state authorization and require states to entertain certified questions. See generally Kurland, Mr. Justice Frankfurter, The Supreme Court and the Erie Doctrine in Diversity Cases, 67 YALE L.J. 187, 214 (1957); 44 ALI Procendings 130-31 (1967) (remarks of Professor Wright). But of. Note, Inter-jurisdictional Certification: Beyond Abstention Toward Cooperative Judicial Federalism, 111 U. PA. L. REv. 344, 357-58 (1963) (suggests that compelling state courts to hear certified questions is not conducive to cooperative federalism, which certification should foster). No congressional statute purports to require state courts to entertain certified questions, however, and the American Law Institute proposal concerning certified questions explicitly disavowed the notion of federal compulsion. AMERICAN LAw INSTITUTE, supra 
in the federal litigation it can cause. ${ }^{57}$ The problem of delay can be greatly alleviated if the state expedites treatment of certified questions, ${ }^{58}$ but in any event certification seems inevitably less time-consuming and less costly than abstention, because the question referred goes directly to the state supreme court. ${ }^{59}$ Not only are its costs less; its benefits are greater. Although certification could share the first two problems discussed in connection with abstention-the question can be raised whether review of certification orders should be allowed and certification can be used as a delaying tactic-it avoids the critical third problem, ${ }^{60}$

note 8 , at 295 .

Congressional power would stem from article III in conjunction with the necessary and proper clause. It may also be that article III gives the federal courts power, without any congressional authoritization, to compel certification. See Note, Consequences of $A b$ stention by $A$ Federal Court, 73 Harv. L. Rev. 1358, 1368 (1960).

${ }^{57}$ See, e.g., American Law INSTITUTe, supra note 8, at 293; Mattis, Certification of Questions of State Law: An Impractical Tool in the Hands of Federal Courts, 23 U. MIAMI L. REv. 717, 725-27 (1969). But see note 59 infra. See also In re Elliott, 74 Wash. 2d 600, 640-41, 446 P.2d 347, 371 (1968) (Hale, J., dissenting).

${ }^{58}$ Presumably Congress could require states to expedite, just as it could require them to provide a certification procedure in the first instance. See note 56 supra. Alternatively, the federal courts could decline to utilize a state's mechanism for certification unless the state gives priority to certified questions. Query whether such a requirement should be imposed, however. See, Thiry v. Atlantic Monthly Co., 74 Wash. 2d 679, 684, 445 P.2d 1012, 1015 (1968) (Hale, J., dissenting) (raising the question why the certified case should "have been given a priority over the several hundred cases already pending" when nothing in its facts warranted unusually expeditious treatment).

59 Justice Wernick, of the Supreme Judicial Court of Maine, states not only that "the extra costs to the litigants in money, energy, time and general inconvenience are likely to be far less in the certification process than in [abstention]," but further that the costs are "likely in any event to be minimal." White v. Edgar, 320 A.2d 668, 683 (Me. 1974). He also says that "certification is likely to provide the litigants with a decision of the highest court of the State, as a definitive determination of the state law issues, almost as speedily as they would have the federal Court's (non-definitive) decision of them (if the federal court does not abstain)." Id. (emphasis added). He concludes that litigants probably would consider whatever costs there are "as, on balance, a price worth paying for the enormous benefit of a reasonably speedy definitive determination of the state law questions." Id.

${ }^{60}$ Moreover, the other two problems are lessened to the extent that certification involves less delay than abstention does. Obviously there is less temptation to use a procedure as a delaying tactic if it results in less delay, and the harm in so using it is also reduced. Apart from reducing delay, there is no way to avoid the problem of misuse of certification, just as there is not with abstention. It seems impossible effectively to police misuse because of the indefinite standards for abstention and certification, and it seems impossible to remove the vagueness from the standards without fundamentally altering the role that abstention and certification are designed to play. See text accompanying notes 62-68 infra. The possibility of misuse, therefore, seems inherent in the doctrines. That possibility can be avoided only by abandoning the doctrines or by truly minimizing the delay that occurs in obtaining clarification of the unclear state issue. See note 59 supra.

There also is less need to review a certification order if little cost and delay is required to obtain the state court's response than if the order burdens the parties more 
that of the unclear state issue never reaching the state supreme court, because the federal court refers the issue there directly. The balance between costs and benefits therefore leaves certification well ahead of abstention, a fact the Supreme Court has recognized recently in suggesting that it would allow certification more freely than abstention. ${ }^{61}$ If the federal judiciary were to adopt the suggestion above of abandoning the abstention doctrine because its costs outweigh its benefits, but were to retain certification, more states might allow certification to their judiciary, in order to fulfill their interest in providing the federal judiciary with their court's answers to unsettled questions of state law.

When a jurisdiction does subscribe to certification, one issue it must face is whether to allow certification only in those circumstances in which abstention has heretofore been proper or instead to permit it more broadly. Insofar as the case for certification is simply its superiority to abstention in a lesser-evil sense, the availability of certification might be limited along Pullman lines. Although the subjectiveness of a requirement that the state issue be unclear is troublesome for some purposes, a requirement of unclarity should certainly be adopted for certification. For unless the certified state issue is quite unclear, there is no need for certification; ${ }^{62}$ the federal district court could safely exercise its pendent jurisdiction and decide the state issue itself. The other criteria for Pullman abstention, however, should not be perpetuated, for they are not sound limitations on an abstention or a certification doctrine. The most basic of these requirements is that the case in which state advice is sought contain a federal constitutional issue. ${ }^{63}$ Another arguable requirement is

severely. The degree of burden to the parties would be a factor as well in determining whether an order could be characterized as final under 28 U.S.C. $\$ 1291$ (1970). See note 18 supra \& accompanying text. Because the extent of delay will vary from jurisdiction to jurisdiction, depending upon such things as the extent of the backlog of the state supreme court and whether certified questions are given priority on the docket, orders of certification should perhaps be final and reviewable in some jurisdictions and not in others. If the parties are substantially burdened by the order it should be reviewable, for the same reasons abstention orders should be, and refusals to certify certainly should not be reviewable. See notes 45-50 supra \& accompanying text.

${ }^{61}$ Bellotti v. Baird, 96 S. Ct. 2857, 2867-68 (1976); Lehman Bros. v. Schein, 416 U.S. $386,390-91$ (1974).

${ }^{62}$ For a case recognizing that a certified question should be unclear, see Thiry v. Atlantic Monthly Co., 74 Wash. 2d 679, 682, 445 P.2d 1012, 1013 (1968).

${ }^{63}$ Propper v. Clark, 337 U.S. 472, 490 (1949) makes it clear that this is a requirement of Pullman abstention. See also Meredith v. Winter Haven, 320 U.S. 228, 236 (1943). Abstention does not, however, always serve the interest of avoiding federal con- 
that the action be one to enjoin a state statute or program. ${ }^{64}$ One reason behind these traditional limitations on Pullman abstention-limitations that are not always followed today ${ }^{65}$-may be to limit abstention to cases in which it is particularly important that the state issue be correctly decided. I would suggest replacing the specific limitations with a general precondition to certification that the state issue on which clarification is sought be an important one; answering the issue correctly should be sufficiently important that deferring to the state supreme court is worth the costs involved. ${ }^{66}$

It is much more costly to make a mistake on some state law issues than others. Just as with Pullman abstention it has not been deemed worth involving two jurisdictions in disputes between two private litigants when erroneous decision of the state issue would not have ramifications beyond the immediate parties, ${ }^{67}$ such disputes should not qualify for certification. At the opposite extreme, consider, for example, a case concerning a right to treatment to be inferred from a state constitutional provision that arguably grants the right but that well may not. Even if a

stitutional adjudication. In Railroad Comm'n v. Pullman Co., 312 U.S. 496 (1941), for example, the district court had avoided decision of the federal issues but the Supreme Court still ordered abstention, thereby furthering the different purpose of avoiding harm to state interests through error on issues of state law. If abstention can be ordered when it serves only that purpose, whether or not the case contains a federal constitutional issue should be irrelevant. The holding of Louisiana Light \& Power Co. v. City of Thibodaux, 360 U.S. 25 (1959), supports this position, although the Court adopted another rationale. See generally Field, supra note 4, at 1093-106, 1136-38.

64 The vast majority of Pullman abstention cases fit this mold, although occasionally the Supreme Court had ordered abstention in cases in which no arm of the state was a party, or in which only damages were sought, without discussing its appropriateness. See Fornaris v. Ridge Tool Co., 400 U.S. 41 (1970) (per curiam); United Gas Pipe Line Co. v. Ideal Cement Co., 369 U.S. 134 (1962) (per curiam).

${ }^{65}$ See note 64 supra.

${ }^{66}$ Of course, in those jurisdictions that manage truly to minimize the costs-by devices such as giving certified questions priority on their dockets-see note 59 supra, the calculus of how readily to abstain would be different than in those jurisdictions in which certification is more time-consuming.

${ }^{67}$ I take this to be the rationale of the Pullman limitations, a rationale reflected in Meredith v. Winter Haven, 320 U.S. 228 (1943), which held abstention unavailable in a simple diversity case. It should be noted, however, that a decision may have broad ramifications even if the state is not a party (or if other traditional limitations are not met). If, for example, a federal court, in an action between private parties erroneously strikes down a state taxing provision, that decision might have as severe consequences for the state as if it were party to the action. $C f$. United Gas Pipe Line Co. v. Ideal Cement Co., 369 U.S. 134 (1962) (per curiam) (vacating judgment of court of appeals to allow construction of city tax ordinance by state courts in contract suit between private parties in which the court of appeals had held the tax ordinance invalid under the commerce clause). If so, it should qualify for certification without regard to whether it is a suit to enjoin state action as unconstitutional. 
federal district court believes that the state supreme court would recognize the right, such an important announcement of state policy arguably should be made by the state judicial system rather than the federal. At least the federal court that is ruling on the issue should require of itself more certainty in the correctness of its result than it would were the issue less significant; if in doubt on such an important issue, the court should refer the question to the state system more readily than it would refer a less important issue. ${ }^{68}$

An obvious disadvantage of a prerequisite to certification that relates to the importance of correct resolution of the state law issue is the subjectivity and indefiniteness of that criterion. It is as vulnerable to these criticisms as the unclarity requirement, the indefiniteness of which is the source of the problems discussed earlier concerning review of abstention decisions and misuse of the abstention procedure. Nonetheless, the aid of the state judicial system should not be sought except when the ramifications of a wrong decision in the particular case will be felt widely and deeply enough to justify the costs of involving the state judiciary. And it is better to address directly the question of the importance of correct decision than it is to adopt a set of criteria (like the traditional Pullman limitations) that overall probably relate to the more significant cases but that may or may not accurately reflect the importance of ruling correctly in a particular case.

If certification is limited to situations in which state law is extremely unclear and in which a mistake on the state law issue could have serious ramifications, and if the delays in the certification procedure can be kept to a minimum, certification may be a satisfactory answer to the abstention dilemma.

${ }^{68}$ The purpose in avoiding state law error in some cases will not be to avoid harm to state interests but instead to avoid unnecessary decision of federal constitutional issues. If, for example, a state statute is challenged as violative of both the state and federal constitutions, and the federal district judge, in the absence of abstention, would uphold the statute under state law, the interest abstention serves is avoiding unnecessary decision of federal constitutional issues. Or, if a state statute is challenged under the Federal Constitution alone, and the statute could be interpreted in such a way that the federal constitutional issue would be avoided, abstention by a federal judge who in the absence of abstention would interpret the statute to raise the constitutional issue will further the purpose of avoiding constitutional litigation. See also notes 50 \& 63 supra.

A requirement that it be important to decide the state issue correctly, in cases in which the purpose of abstention is to avoid federal constitutional decisionmaking, would call for a judgment whether the constitutional question is of a type that should be avoided. If it were a routine or settled question for example, the importance criterion would not be satisfied and certification would be improper. 